TPeriodica Polytechnica Civil Engineering

62(4), pp. 921-929, 2018

https://doi.org/10.3311/PPci.11748

Creative Commons Attribution (i)

RESEARCH ARTICLE

\section{Flexural Performance of Hybrid Engineered Cementitious Composite Layered Reinforced Concrete Beams}

\author{
Ammapalayam Ramasamy Krishnaraja ${ }^{1^{*}}$, Shanmughasundaram \\ Kandasamy $^{2}$ \\ Received 25 November 2017; Revised 27 March 2018; Accepted 18 April 2018
}

\begin{abstract}
This paper presents the experimental investigation to evaluate the flexural performance of newly developed hybrid Engineered Cementitious Composite (ECC) layer at tension zone around the main reinforcement of beam. Four different ECC mixes are used in the beam to evaluate the flexural performance, hybrid ECC based on the low modulus poly vinyl alcohol (PVA) and high modulus steel short random fibre reinforcement. The aim of hybridation is to improve the flexural, energy absorption and ductility performance of reinforced concrete beams. In addition to the compressive strength, young's modulus, uniaxial tensile strength and bond strength of ECC mixes are determined. ECC with PVA fibre with $2.0 \%$ volume fraction mix is kept as reference mix, hybridation is made with PVA (1.35\%) and steel (0.65\%), PVA (1.00\%) and steel (1.00\%) and finally with PVA (0.65\%) and steel (1.35\%). This hybridization has a remarkable achievement in mechanical properties and in the flexural behavior in ECC layered RC beam. From the results, it has been observed that mono fiber ECC reinforced with PVA of $2.0 \%$ and hybrid fiber ECC reinforced with $1.35 \%$ of PVA fiber and $0.65 \%$ of steel fiber has reasonable flexural characteristics than the conventional beam.
\end{abstract}

\section{Keywords}

Engineered Cementitious Composite, direct tensile, flexural strength, bond strength, energy absorption

\footnotetext{
1 Department of Civil Engineering,

Kongu Engineering College, Perundurai,

Tamilnadu - 638060, India

2 Department of Civil Engineering,

Government College of Technology,

Tamilnadu - 641013, India

* Corresponding author, email: krajacivil@gmail.com
}

\section{Introduction}

This It has been demonstrated in the past few decades that the cement based composite material can be reinforced with short random fibers of volume fraction less than $2.0 \%$. This material is designed to confirm the tensile strain hardening, cracking behavior after initial crack, fiber bridging and multiple cracks. Such material is referred to as Engineered cementitious composite (ECC) and it also belongs to the family of ultra high toughness cementitious composite (UHTCC). ECC mixes are generally developed with polyvinyl alcohol (PVA) fiber, polypropylene (PP), steel (SE) fiber and polyethylene (PE) fiber. The reason for introducing these fibers is to improve the performance of the structural member, which assists a damage reduction in the concrete structure subjected to seismic and impact effect [1]. It has been experimented in various structural applications and proved its excellent structural strength, energy absorption, highly ductile, toughness, strain hardening and reasonable fracture energy under static and cyclic loading conditions, resistance against the severe environmental exposure; more over it is a maintenance free material [2]. In the case of permeability, ECC exhibits excellent sounding material than the concrete, even after the strain load of $1.5 \%$ and this is because of very low crack width [3].

ECC plays the major role in strengthening of beams and its application exhibits better performance than the fiber reinforced polymer (FRP). In the case of FRP, debonding failure appears due to normal stress and interfacial shear concentrations at crack points subjected flexural load in reinforced concrete beams [4]. The presence of ECC in the tensile face of the concrete beam displayed thinner multiple cracks under flexural loading reducing the crack induced stress concentration in the beam. It results in the efficient stress distribution in the tension zone of the beam [5]. In recent years, full scale of application of ECC has been carried out in various infrastructures. Some renowned application include cast in place of ECC link slab in bridges [6], retrofit Mitaka Dam in Japan [7] sprayed UHTCC tunnel linings in South Korea, irrigation channel repairs in Japan [8]. It has been used as a damper in a building located in tokyo and yokohama [9], irrigation 
channel in shiga, retaining wall and in via duct [10]. The Shear resistance of ECC has been evaluated by Yongxing Zhang [11] during 2016. The results showed that ECC is enhanced to take the shear and failure occurred with multiple cracking which is influenced with effect of shear transfer behavior on cracked surface and also due to the effect of fiber bridging. ECC behaves as an excellent retrofitted material in an unreinforced masonry wall subjected to lateral cyclic loading. Two different ECC has been developed with mono PVA fiber with $2.0 \%$ volume fraction and hybridation of PP with $1.5 \%$ volume fraction and PE with $0.5 \%$ volume fraction and applied with spray-able technique. Both ECC mixes performed better in load carrying capacity, ductility, stiffness than the wire mesh retrofitted masonry wall [12].

\section{Research significance}

The application of ECC may be expanded for various infrastructure sectors in the future. There are certain limitations in various applications where mono fiber ECC is used and so, there is a need to improve the properties of the ECC with mono fiber. PE, PVA and PP have better performance in strain hardening, ductility with least amount of load under tension, thus, it is categorized under low modulus fiber [13]. The high modulus fibers such as glass fiber, steel fiber and carbon fibers exhibit high tensile strength, toughness and in build brittle nature which does not allow for strain hardening and ductility [14-18]. The Hybridation in the ECC with low modulus fiber and high modulus exhibits notable improvement in the mechanical properties of the ECC mix [19-21] and more over there is a notable improvement in the flexural strength under elevated temperature when short steel fibers hybrid with polymeric fibers [22]. In this study, the focus is to develop a new cementitious composite by incorporating PVA as low modulus fiber and steel fiber as high modulus with improved mechanical properties, flexural behavior and ductility properties. For examining various behaviors, hybridation is formed by replacement of PVA fibre by steel fiber with $0.65 \%, 1.00 \%$ and $1.35 \%$ of volume fraction. ECC with $2.0 \%$ volume fraction of PVA fiber is kept as reference mix.

\section{Materials and mixes}

\subsection{Materials and mix proportions}

Table 1 shows the chemical composition of OPC 53 grade cement and Class F fly ash collected from Mettur thermal power plant, Tamilnadu, India used in this study. Similarly, Table 2 shows the physical and mechanical properties of PVA fiber and steel fiber. Mixes used, to develop the new hybrid ECC, in this study are shown in Table 3. ECC mix does not include coarse aggregate to enhance the fiber dispersion in the mix and fracture toughness, as they are advantageous to achieve the tensile ductility. Table 4 shows the mix design of grade M30 concrete as per IS-10262:2009 [23] used for reinforced concrete beams subject to flexural load and Fe500 grade steel reinforcement used in beams. Super plasticizer confirming to IS: 9103:1999 [24] is added in the ECC and concrete mixes to improve the workability in fresh state. Mixes are named as M1, M2, M3 and M4. M1 ECC mix has been prepared with PVA mono fiber reinforcement of volume fraction $2.0 \%$ whereas M2 ECC mix is made with hybridation of PVA fiber and steel fiber of volume fraction of $1.35 \%$ and $0.65 \%$ respectively. M3 mix contains $1.0 \%$ volume fraction in each fiber. Similarly, M4 ECC mix is with hybridation of PVA fiber of volume fraction $0.65 \%$ and steel fiber of volume fraction of $1.35 \%$. The hybridation of steel fiber with PVA is to improve the mechanical and flexural characteristics of ECC.

\subsection{Mix preparation}

Powdered ingredients in ECC such as Cement, fly ash and sand are first placed in the mixer machine and mixed at low speed for five minutes [25]. Water and super plasticizer admixture were mixed together and added to the dry mix in the mixer machine for further three minutes. The preparation of Mixes ended three to five minutes after fibers are added in the cement paste. The whole process of mix preparation took for about 15 minutes. There are some advantages in preparing mix for 15 minutes as it minimizes the effects due to thixotrophy [26]. Increase in mixing duration show the way to distribution of fibers evenly and balling effects are completely eliminated in the mix [27]. But there must not be any balling effects due to the addition of fiber in the fresh ECC with bare hands. After the placing of mixes in their respective steel moulds, natural external compaction is not encouraged in ECC mixes due to flowability and self consolidation. After 24 hours curing in room temperature, the specimen of are demoulded from respective moulds. Then the specimens are allowed to cure in water for 28 days and later on preferred tests are carried out. Fig. 1 shows the casting of dog bone specimen and cube specimen.

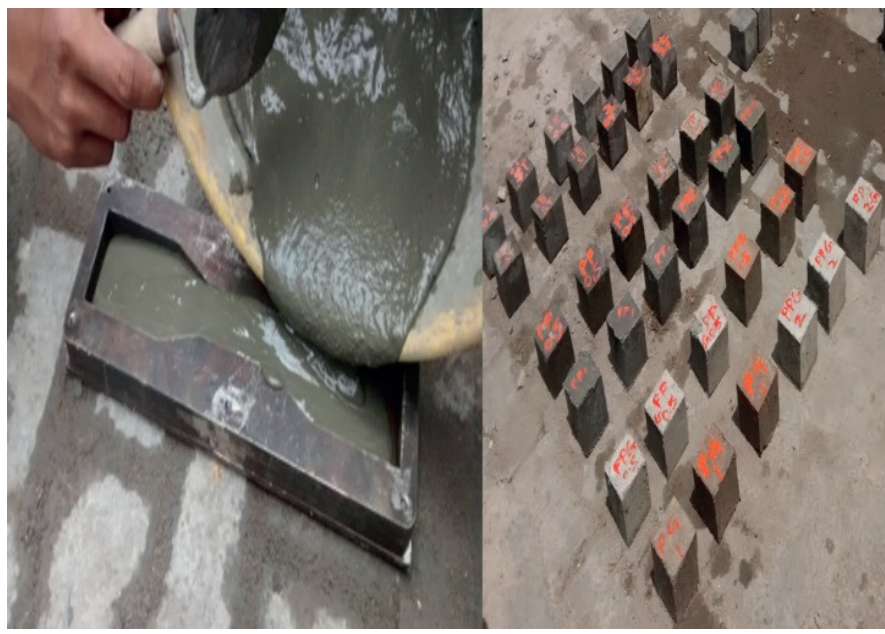

Fig. 1 Casting of dog bone specimen and cube specimen 
Table 1 Chemical composition of cement and fly ash

\begin{tabular}{lccccccc}
\hline & $\mathrm{CaO}(\%)$ & $\mathrm{SiO}_{2}(\%)$ & $\mathrm{Al}_{2} \mathrm{O}_{3}(\%)$ & $\mathrm{Fe}_{2} \mathrm{O}_{3}(\%)$ & $\mathrm{MgO}(\%)$ & $\mathrm{SO}(\%)$ & $\mathrm{Alkalines}(\%)$ \\
\hline Cement & 63.71 & 22.30 & 4.51 & 3.39 & 1.77 & 2.59 & 1.73 \\
Fly ash & 5.31 & 55.37 & 29.74 & 7.88 & 1.48 & 0.22 & -- \\
\hline
\end{tabular}

Table 2 Physical and mechanical properties of fibre

\begin{tabular}{lccccccc}
\hline Fibre & Diameter $[\mu \mathrm{m}]$ & Length $[\mathrm{mm}]$ & 1/d ratio & Density $\left(\mathrm{g} / \mathrm{cm}^{3}\right)$ & Nominal tensile trength $[\mathrm{MPa}]$ & Elongation at break $[\%]$ & Young's modulus MPa] \\
\hline PVA & 39 & 12 & 308 & 1.3 & 1600 & 6 \\
Steel & 300 & 12 & 40 & 7.9 & 2000 & 42.5 \\
\hline
\end{tabular}

Table 3 Mix design of ECC

\begin{tabular}{|c|c|c|c|c|c|c|c|}
\hline Mix Designation & Cement & Fly ash & Sand & Water/Binder ratio & Super Plasticizer [\%] & PVA Volume [\%] & Steel Volume $[\%]$ \\
\hline M1 & 1 & 0.43 & 0.71 & 0.35 & 1.0 & 2.0 & -- \\
\hline M2 & 1 & 0.43 & 0.71 & 0.35 & 1.0 & 1.35 & 0.65 \\
\hline M3 & 1 & 0.43 & 0.71 & 0.35 & 1.0 & 1.0 & 1.0 \\
\hline M4 & 1 & 0.43 & 0.71 & 0.35 & 1.0 & 0.65 & 1.35 \\
\hline
\end{tabular}

Table 4 Mix design of Convention concrete

\begin{tabular}{lccccc}
\hline Cement & Fly ash & Sand & Course Aggregate (12 mm) & Water/Binder ratio & Super Plasticizer [\%] \\
\hline 272.8 & 68.2 & 730 & 1235 & 0.4 & 0.9 \\
\hline
\end{tabular}

\section{Test methods}

\subsection{Uniaxial compression and young's modulus tests}

A $70.7 \times 70.7 \times 70.7 \mathrm{~mm}$ cube specimens are used to decide the compressive strength of ECC mixes after 3 days, 7 days, 21 days and 28 days curing according to IS 4031- Part 6: 1988 [28]. For each mix, three specimens are casted and tested taking the average value in to account. To determine the young's modulus, cylinder with $100 \mathrm{~mm}$ in diameter and $200 \mathrm{~mm}$ in length is used.

\subsection{Direct tensile test}

The dog bone specimen is used to examine the direct tensile strength of ECC specimens. $330 \mathrm{~mm} \times 60 \mathrm{~mm} \times 30 \mathrm{~mm}$ size [29-31] has been used. The uniaxial direct tensile test is carried using Zwick/roell Z100 universal testing machine of capacity $100 \mathrm{kN}$ with a gauge length of $80 \mathrm{~mm}$ with a cross section of $30 \mathrm{~mm} \times 30 \mathrm{~mm}$ after 28 days. Fig. 2 shows the test setup and specimen details for direct tensile test.

\subsection{Bond strength}

The common splitting cube tests are used to find out the bond strength between two interface layers of conventional concrete and ECC material [32]. A $150 \mathrm{~mm}$ cube mould is used to cast the specimen for bond strength test, ECC mixes were place for a height of $75 \mathrm{~mm}$ and later, the remaining portion of the cube specimen is filled with conventional concrete. After 24 hours, the specimens are demoulded and allowed to cure in water for 28 days. The compression testing machine of $200 \mathrm{kN}$ is used to test the bond interface between the layers. The test set up and specimens are shown in Fig. 3.
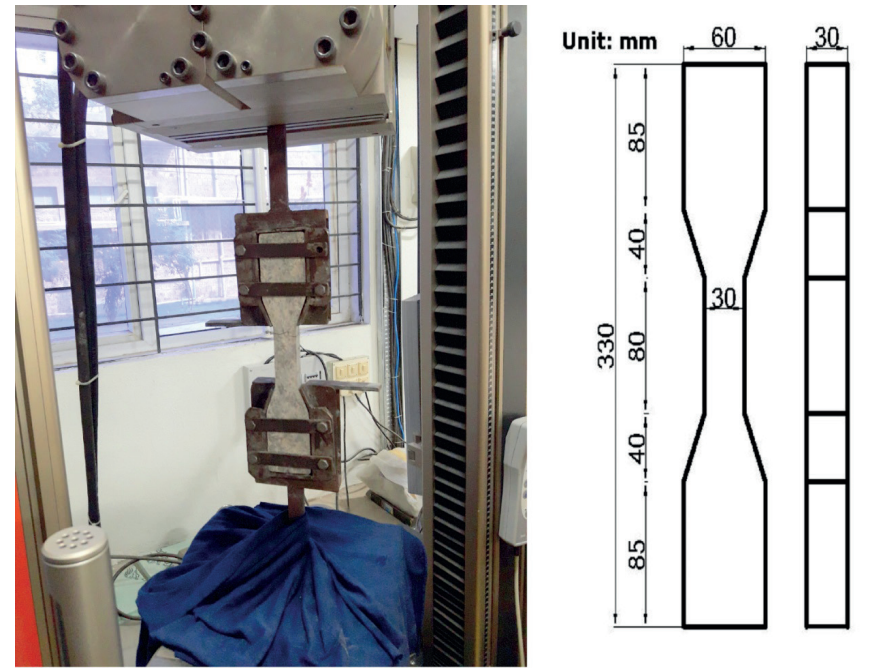

Fig. 2 Direct tensile test specimen detail (Dog Bone Specimen)

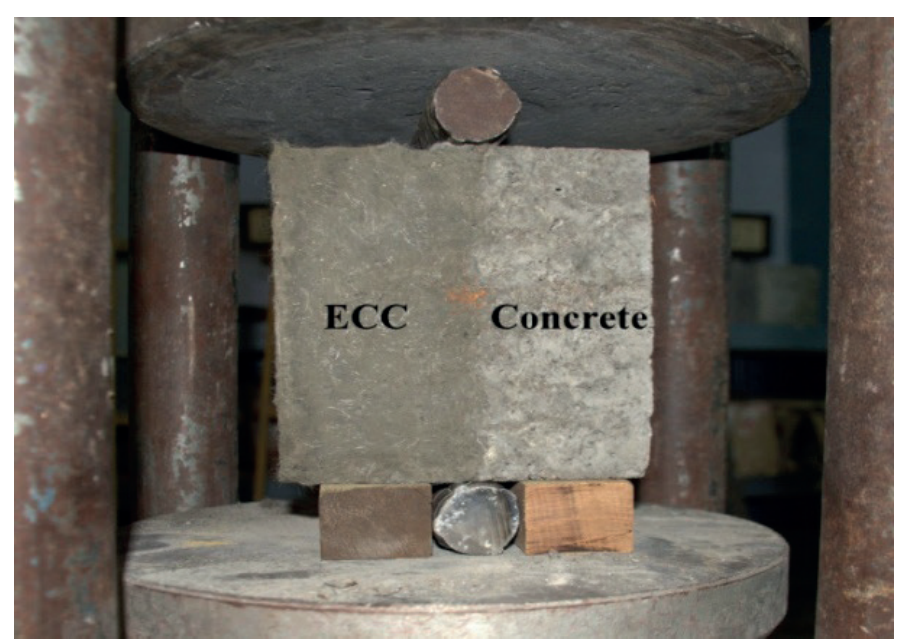

Fig. 3 Bond test on conventional concrete cube 


\subsection{Flexural behaviour of ECC layered reinforced concrete beams}

The four point load test is applied on the reinforced concrete beams on the effective span of $1800 \mathrm{~mm}$ and tests have been carried out at room temperature and as per standards. Fig. 4 shows the dimension parameters, reinforcement details and position of ECC layer. Concrete beams have been designed as under reinforcement sections with an overall length of 2000 $\mathrm{mm}, 100 \mathrm{~mm} \times 150 \mathrm{~mm}$ cross sections and it is reinforced with 2 numbers of $8 \mathrm{~mm}$ diameter bars at bottom and 2 numbers of $6 \mathrm{~mm}$ diameter bar as a hanger reinforcement at top. In addition, 2 legged $6 \mathrm{~mm}$ diameter is spaced at $100 \mathrm{~mm}$ centre as shear reinforcement. The beam is cast in the way that ECC mixes are initially placed inside the mould for a thickness of $30 \mathrm{~mm}$. After an hour, the conventional concrete is placed over the ECC layer up to top level of the beam as this is to improve the bonding between two layers and avoid the course aggregate enter in to the ECC layer. Special care is taken while applying the external compaction on concrete layer. During the mixing process of ECC, thixotropic effect of fiber is avoided by earlier discussed procedure. Fig. 5 shows the four point load test setup on beam. The Push pull hydraulic jack of $100 \mathrm{kN}$ capacity is used to apply load on the four point load setup of beam, below which load cell is placed and used to measure the applied load on the beam. Linear variable differential transformers (LVDT) are placed in three places at the bottom of the beam below the load acting point and mid span. LVDT and Load cell are connected with data acquisition system. The readings and data are reordered and stored with the help of computer. From flexural test, parameters like Load deflection curve, energy absorption of section and displacement ductility have been evaluated whereas the energy absorption of section is calculated by measuring the area between yield points to breaking point. Ratio between the ultimate deflections to the yield deflection of the beam is said to be displacement ductility [33-35].

\section{Results and discussion}

\subsection{Uniaxial compression and young's modulus tests}

The compressive strength of all mixes at 3, 7, 21 and 28 days is displayed in Fig. 6. Three specimens are tested for each mix and an average compressive strength is measured. M1, M2, M3 and M4 mixes exhibit the 28 days compressive strength of 51MPa, 51.8 MPa, 52.1MPa and 53.2 MPa respectively. It can be observed from the results there is a noteworthy attainment of compressive strength for all the mixes. Compressive strength of ECC mixes after 3 days of curing is $18.4 \%, 18.8 \%, 18.9 \%$ and $19.5 \%$ of the 28 days compressive strength of M1, M2, M3 and M4 ECC mixes respectively. Similarly, compressive strength of ECC mixes after 21 days curing is observed as $74.9 \%, 90.3 \%$, $91.4 \%$ and $73.9 \%$ of the 28 days compressive strength for M1, M2, M3 and M4 ECC mixes. From the compressive strength

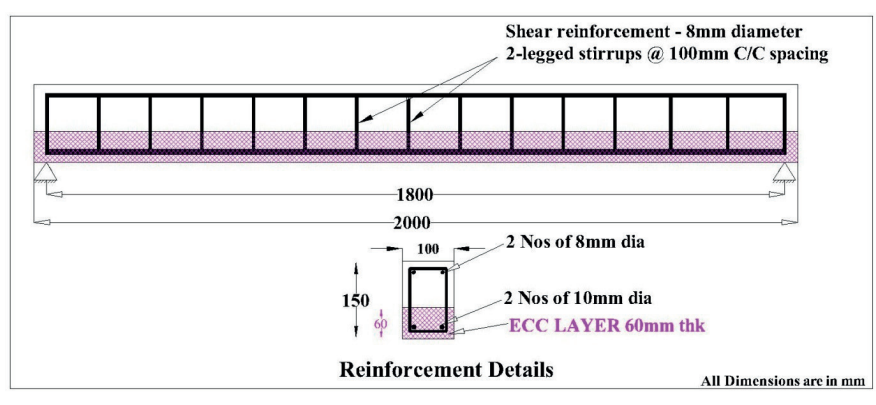

Fig. 4 Dimension parameters, reinforcement details and position of ECC layer

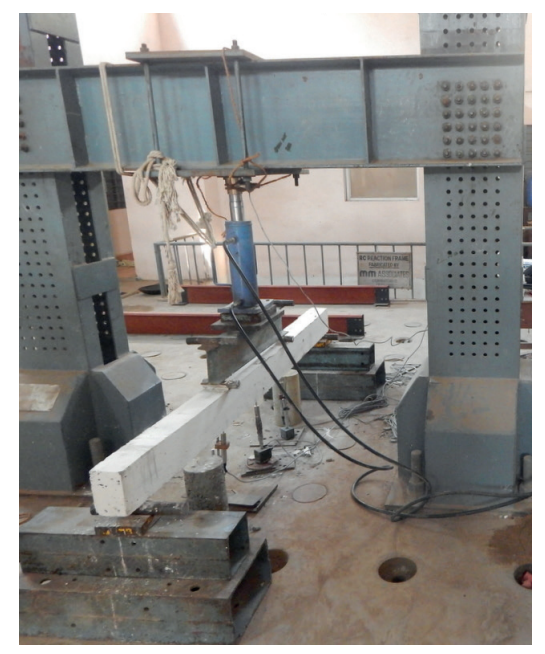

Fig. 5 Four point load test setup on beam

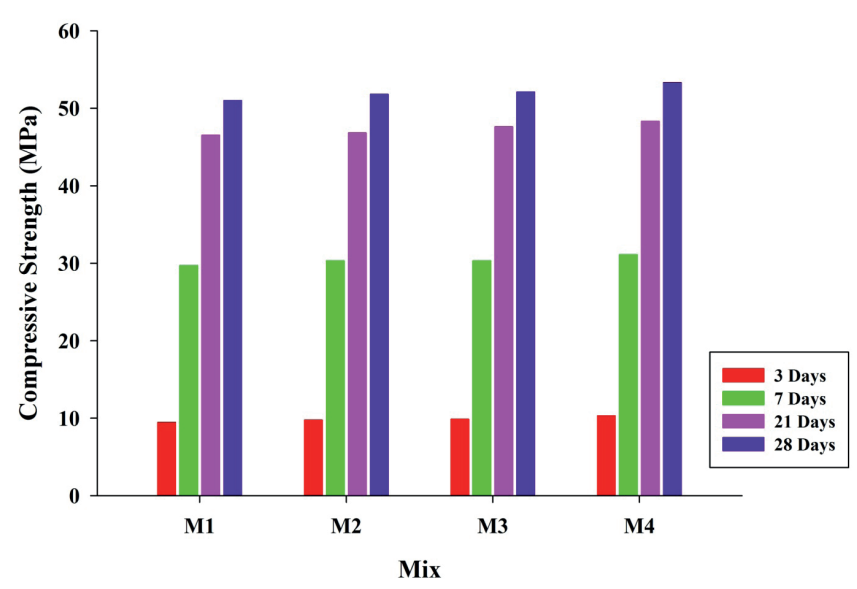

Fig. 6 Compressive strength of ECC mixes
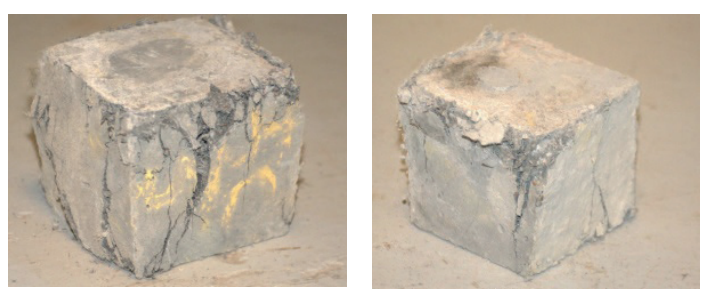

Fig. 7 Typical failure pattern of ECC cubes

results, it can be observed that the presence of steel by hybridation process does not offer any extra compressive strength. However, ECC mixes are ductile under compressive load, without losing any fragments around the cubes and this is due to the fiber bridging effect of fibers in the ECC mixes [36]. Fig. 7 Shows the typical failure pattern of ECC mixes. 


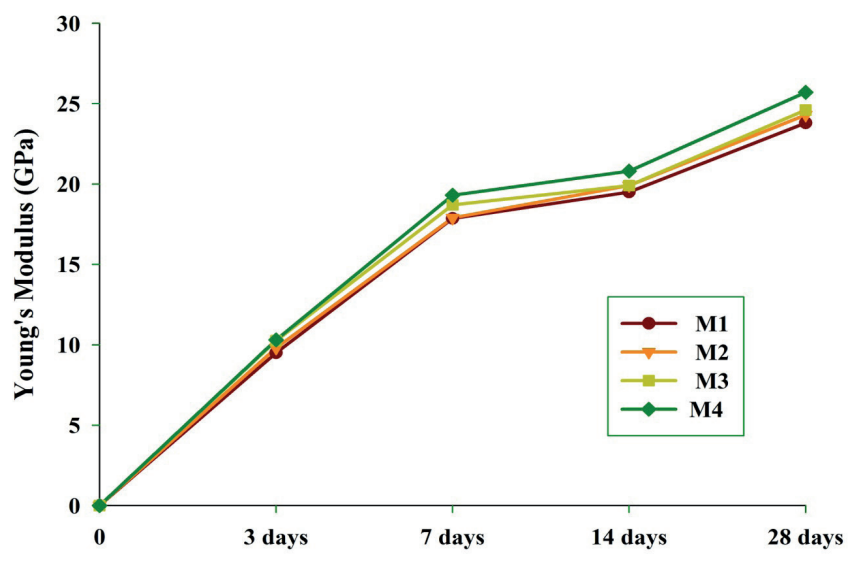

Fig. 8 Young's modulus of ECC mixes

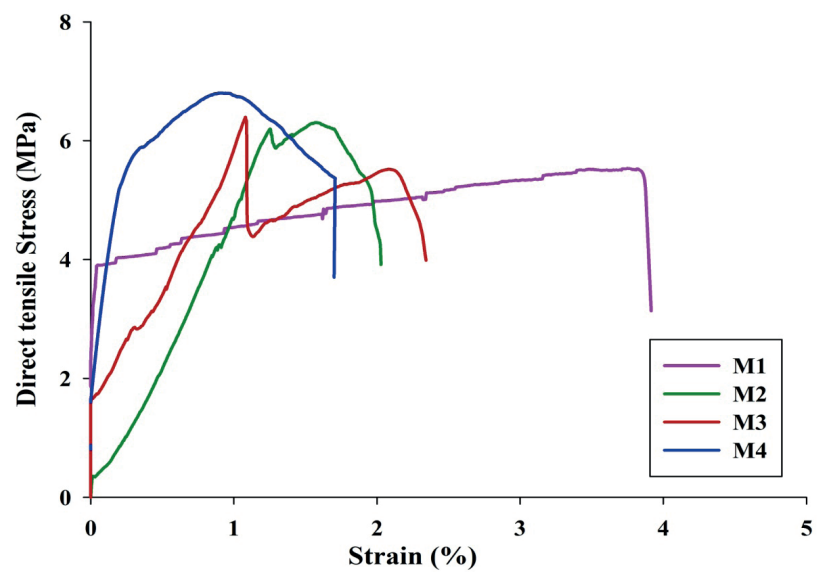

Fig. 9 Stress strain curve of direct tensile test

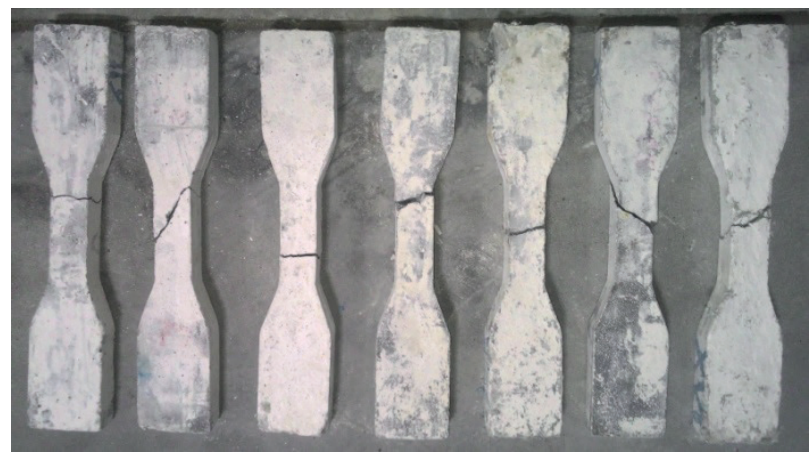

Fig. 10 Failure pattern of ECC specimen under direct tensile load

A cylinder specimen is used to determine the young's modulus of different mixes and the average is shown in Fig. 8. From the results, it can be observed that the lack of course aggregate in the specimen influences the young's modulus value obtained [37]. Mixes M1, M2, M3 and M4 exhibit 23.8 MPa, 24.3 MPa, 25.1 MPa and 25.8 MPa young's Modulus after 28 days of curing. M1 and M2 mixes displayed similar results at the period of 3, 7 and 21 days and the variation between $\mathrm{M} 1$ and M2 mixes is $3.9 \%$. M3 mix is $6.5 \%, 2.2 \%$ and $4.3 \%$ greater than the M1 mix at the age of 3, 7 and 21 days respectively. Similarly, mix M4 is $9.8 \%, 8.9 \%$ and $7.2 \%$ greater than the M1 mix after 3, 7 and 21 days of curing respectively. There is a reasonable improvement in the young's modulus of ECC due to the presence of steel fibers in the ECC mixes.

\subsection{Direct tensile test}

All Direct tensile tests are performed on the dog-bone specimens with cross section of $30 \mathrm{~mm} \times 30 \mathrm{~mm}$ and a gauge length of $80 \mathrm{~mm}$ specimens to confirm the ductile strain hardening performance of the hardened composite. Specimens are cured for 28 days and as usual, three specimens for each mixes are used to determine the average direct tensile strength.

The application of ECC in the constructional field is increasing extensively day by day and it is essential to study the behavior of ECC to define the role of application. The Zwick/Roell Z100 universal testing machine of capacity 100 $\mathrm{kN}$ is used to conduct the test. Fig. 9 shows the stress strain curve ECC mixes under direct tensile test. The maximum stress is called as the tensile strength, and the corresponding strain is defined as the maximum tensile strain capacity of the specimen. Mix M1 Exhibits the maximum tensile strength of $5.53 \mathrm{MPa}$ and maximum tensile strain of $3.9 \%$ whereas the tensile strength of mix M2 is increased by $15.6 \%$, M3 mix is increased by $13.9 \%$ and the M4 mix tensile strength is $22.7 \%$ higher than the reference mix. The first crack tensile strength of M1, M2, M3 and M4 mixes occurs at 4.05 MPa, 4.43 MPa, 4.58 $\mathrm{MPa}$ and 5.31 MPa respectively. The typical failure crack pattern of dog bone specimen is shown in Fig. 10. The Guidelines given by victor $\mathrm{Li}[38$ ] to define the composite material as ECC is that the ultimate tensile strength of ECC should be within 4-12 MPa and similarly the ultimate tensile strain should be within 1-8\%. In this study, the ultimate strength of all the four mixes is between $5.53-6.78 \mathrm{MPa}$ which is within the specified range. However, the strain hardening properties of steel hybrided ECC mixes exhibit low value. The mixes M1, M2, M3 and M4 exhibit strain value of 3.9\%, 1.56\%, 1.08\% and $0.98 \%$ respectively. The presence of steel fiber in the ECC mixes decreases the strain hardening nature owing to the limited elongation nature of steel fiber. However, mix M4 has failed to attain the strain capacity of $1.0 \%$ though the range is very close to the guideline given by Victor Li.

\subsection{Bond strength between concrete substrate and ECC material}

Fig. 11 shows the bond strength between concrete substrate and different ECC mixes after 7, 21 and 28 days curing. From the figure, it can be observed that the bond strength of conventional concrete exhibits $0.85 \mathrm{MPa}, 1.24 \mathrm{MPa}$ and $2.79 \mathrm{Mpa}$ after 7,21 and 28 days of curing respectively. This is $20 \%, 24.2 \%$ and $25.4 \%$ less than the M1 mix for three different stages of curing. Similarly, mix M2 is $15.3 \%, 19.4 \%$ and $21.5 \%$ greater than the conventional concrete bond strength. Mixes M3 and M4 displays the bond strength of each $1.04 \mathrm{MPa}$ after 7 days of curing; $1.57 \mathrm{MPa}$ and 1.55 MPa bond strength after 21 days of curing. After 28 days curing, the bond strength for M3 and M4 mixes were $3.75 \mathrm{MPa}$ and $3.63 \mathrm{MPa}$ respectively. From the results, it is observed that the presence of steel fiber in the 


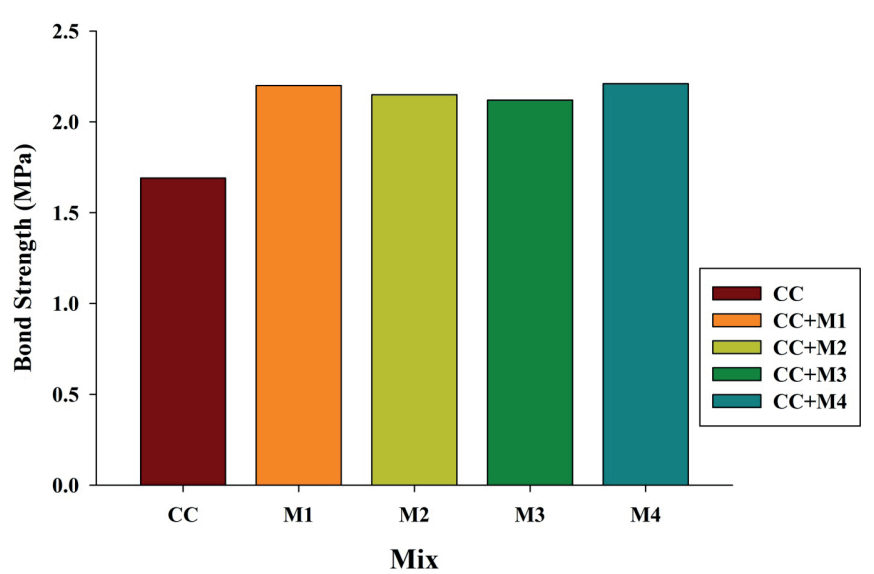

Fig. 11 Bond Strength

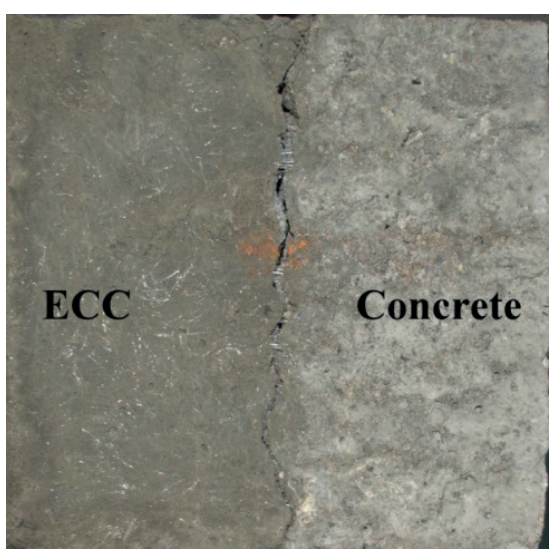

Fig. 12 Surface interface failure under split load

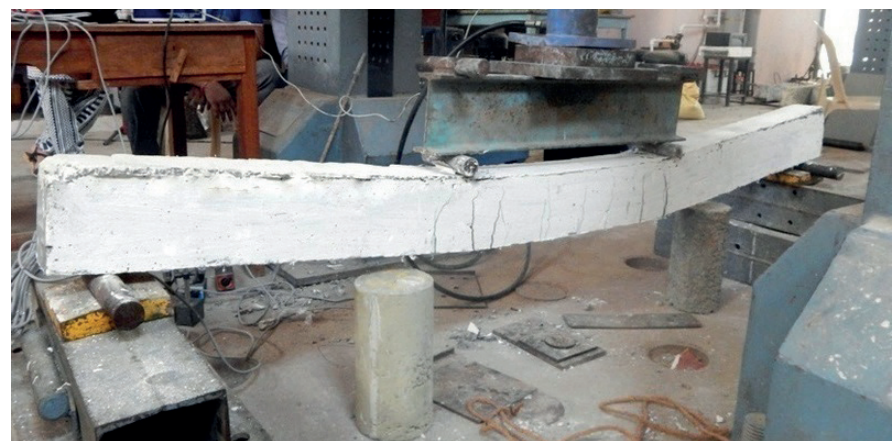

Fig. 13 Flexural behavior of ECC layered beam under ultimate loading

ECC mix increases the bond strength and in mono fiber ECC mix, bond strength improves with the presence of PVA fiber. Fig. 12 shows the failure in the surface interface of composites after bond test. From the failure interface, it is observed that there are no issues about the bonding effects between concrete and ECC interface. Failure interface shows the presence of the
ECC mixes in both sides of failure interface. In case of conventional concrete, the failure interface shows the presence of the aggregate. Moreover, in RCC beam stirrups provided in the beams act as a shear connector between the interfaces.

\subsection{Flexural behaviour of RCC beam}

The four point bending test is carried out on the 2.0 meters reinforced concrete beams to examine flexural behavior, load deflection curves, exhibited initial crack, yielding point, ultimate and failure stages. Fig. 13 shows the flexural behavior of ECC layered beam under ultimate loading and Table 5 shows the features of load deflection values such as first crack, yielding, ultimate and failure. Till yield stage, all the beams behaved with similar performance under flexure and the first crack occurred in all the mixes within the yielding stage; the intensity of initial cracking load is in the range of $4.07 \mathrm{kN}$ to $6.27 \mathrm{kN}$. After yielding stage, cracks developed between the load positions/mid span of the beam which is due to the loading nature of the beam. The harden properties of ECC mixes under tensile/flexural load ensured that the load does not decreases rapidly after the initial crack and brittle mode of failure of ECC layered beams are different from convention beams and strain property of ECC layered beams are notable one.

The multiple and finer cracks developed in the tension face of the beam after yielding, which slightly influences the strength, durability and performance of the structure $[39,40]$. The occurrence of cracks in all the specimens increased with the increase in flexural load. However, at particular stage, the new cracks development has not increased in the beam [41]. Due to higher ductility nature of ECC mixes, the load deflection curves for layered beams are wider than the conventional concrete curve. Fig. 14 shows the load deflection curve for various beams. From the experimental results, it is observed that there has been noteworthy development in the beams with ECC layers. In connection with the ultimate load carrying capacity, ECC with PVA with $0.65 \%$ volume fraction and Steel with $1.35 \%$ of volume fraction performed better among all the mixes which is $1.22,1.13,1.09$ and 1.03 times greater than conventional concrete beam, M1, M2 and M3 ECC layered concrete beams respectively. However, in this case, energy absorption of section ECC with PVA mono fiber of volume fraction 2.0 exhibits higher among all the mixes which are due to the high elongation nature and bridging effect of PVA fiber

Table 5 Salient Features of Load Deflection Curve

\begin{tabular}{|c|c|c|c|c|c|c|}
\hline Mix ID & $\begin{array}{l}\text { First Crack Load } \\
\qquad(\mathrm{kN})\end{array}$ & $\begin{array}{c}\text { Deflection@ } @ \text { First } \\
\text { Crack (mm) }\end{array}$ & $\begin{array}{l}\text { Yield Load } \\
\quad(\mathrm{kN})\end{array}$ & $\begin{array}{c}\text { Deflection@ } \\
\text { Yield Load (mm) }\end{array}$ & $\begin{array}{l}\text { Ultimate Load } \\
\qquad(\mathrm{kN})\end{array}$ & $\begin{array}{c}\text { Deflection@ } \\
\text { Breaking Load (mm) }\end{array}$ \\
\hline $\mathrm{CC}$ & 4.07 & 0.19 & 8.3 & 1.37 & 18.1 & 25 \\
\hline M1 & 4.27 & 0.13 & 11.05 & 0.75 & 19.4 & 35.8 \\
\hline M2 & 4.88 & 0.09 & 11.3 & 0.71 & 20.16 & 34.1 \\
\hline M3 & 5.35 & 0.045 & 11.29 & 0.63 & 21.3 & 29.14 \\
\hline M4 & 6.27 & 0.038 & 13.25 & 0.61 & 22.065 & 26.9 \\
\hline
\end{tabular}




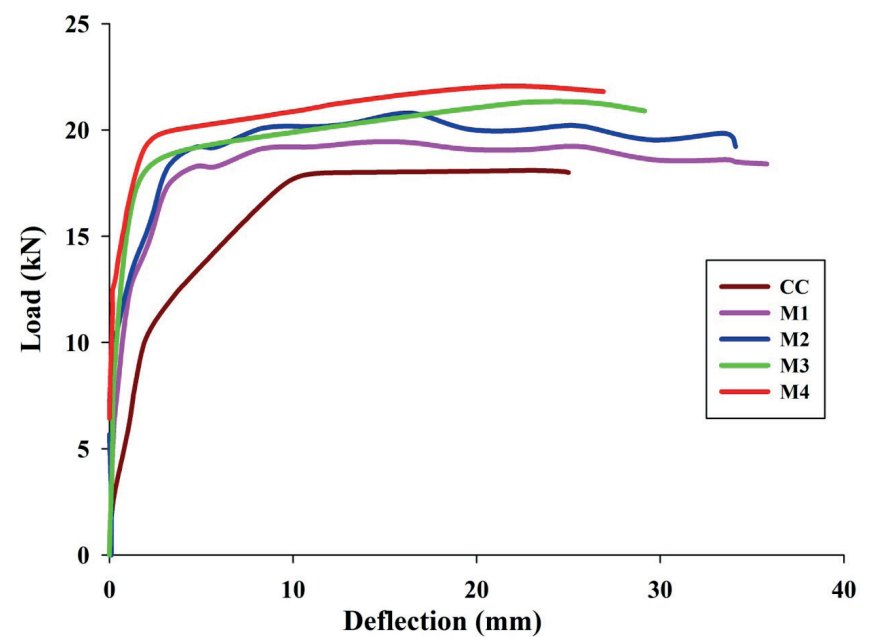

Fig. 14 Load Deflection curve of various beam

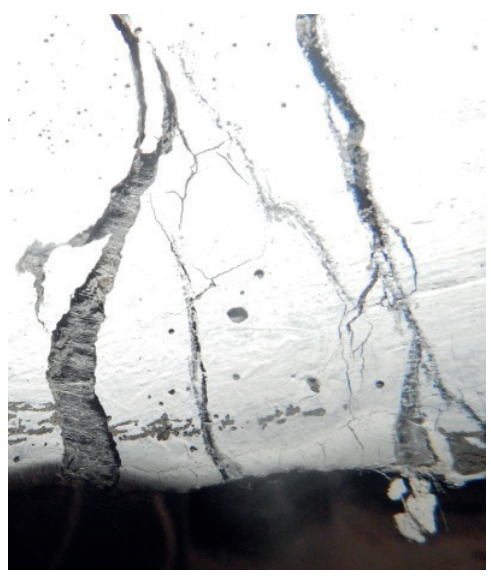

Fig. 15 Fiber bridging effects in ECC layer

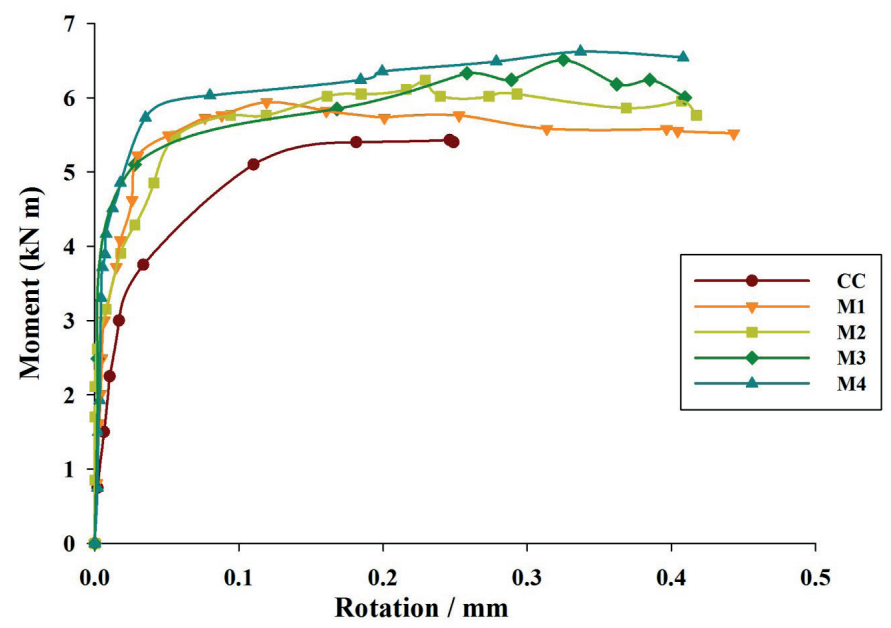

Fig. 16 Moment curvature of various beam

Table 6 Energy Absorption, Displacement and Energy Ductility of RCC Beams

\begin{tabular}{lcc}
\hline Mix ID & Energy Absorption (kN.mm) & Displacement Ductility \\
\hline CC & 384 & 18.2 \\
M1 & 661 & 47.7 \\
M2 & 648 & 48.0 \\
M3 & 571.5 & 46.3 \\
M4 & 516 & 44.1 \\
\hline
\end{tabular}

than the steel fiber. Fig. 15 shows the fiber bridging in ECC layer under flexural loading, it clearly stated that fibers in ECC mixes are evenly distributed and free from balling effects.

The energy absorption capacity of section is the area under the yield point to the ultimate point in the load deflection curve. M1 ECC layered beam revealed $661 \mathrm{kN}$ mm energy absorption in section, which is $1.7,1.02,1.15$ and 1.28 times greater than conventional concrete beam, M1, M2 and M3 ECC layered concrete beams respectively. Table. 6 shows the energy absorption displacement and energy ductility of ECC layered Beams. On the other hand, PVA with $1.0 \%$ volume fraction and Steel with $1.0 \%$ of volume fraction exhibited admirable improvement in the energy absorption and ductility behavior. The displacement ductility of M2 mix is 48, which is $62 \%$, $0.6 \%, 3.5 \%$ and $6.7 \%$ greater than the conventional concrete, M1 mix, M3 mix and M4 mix layered beams respectively. Figure. 16 shows the moment curvature of the conventional concrete and ECC mixes, from the figure it was observed moment rotation behave similar to the load deflection curve.

\section{Conclusions}

An experimental investigation on the mechanical properties and flexural performance of ECC layered beams with four different mixes using with PVA fibers and steel fibers has been carried out in the present work. Based on the investigation results, the following conclusions have been arrived:

- The hybridation of steel fiber with PAV fiber does not improve the compressive strength of ECC mix. However, there is a notable improvement in the young's modulus properties

- The tensile test on dog bone specimen proves that the addition of steel fiber exhibited excellence in tensile strength; on the other hand it failed to perform in the strain hardening part. All the specimens failed in the designed $30 \mathrm{~mm}$ x 30 mm cross section

- The Bond strength test proves that there is exceptional surface interface bond between concrete and different ECC mixes. The same is revealed in the flexural test on reinforced concrete beam; crack developed in the ECC layer is propagated up to compression zone before failure and there is no surface interface failure

- The typical failure mode of conventional concrete beams is abrupt with the minimum number of larger width cracks. The crushing of concrete also occurred while the rupture is observed in the ECC layered beams with multi point cracks in the tension zone owing to bridging of fibers before failure; and also no spilling occurred during breaking load

- The presence of ECC layer greatly improves the cracking load, yielding load and ultimate load compared with the conventional concrete beam. The strain hardening of ECC layer in the concrete beam increases the load bearing capacity, deflection, energy absorption and ductility. 


\section{Acknowledgement}

The PVA fibers used in this research work has been funded by Kuraray private limited, India. Uniaxial tensile test is conducted at PSGTECHS COE INDUTECH (Promoted by Ministry of Textiles - Government of INDIA), Department of Textile Technology/Automobile Engineering- PSG College of Technology, Coimbatore.

\section{References}

[1] Li, V.C., Kong, H.-J., Bike, S.G. "Fiber reinforced high performance concrete material". In: High Performance Concrete-Workability, Strength and Durability. (Chris, L., Zongjin, L., Jian, D. (Eds.)). pp. 71-86. 2000.

[2] Kunieda, M., Rokugo, K. "Recent progress on HPFRCC in Japan". Journal of Advanced Concrete Technology, 4(1), pp. 19-33. 2006. https://doi.org/10.3151/jact.4.19

[3] Lepech, M., Li, V. C. "Water permeability of cracked cementitious composites". In: Proceedings of ICF11, pp. 113-130. 2005.

[4] Maalej, M., Leong, K. "Engineered cementitious composites for effective FRP-strengthening of RC beams". Composites Science and Technology, 65(7-8), pp. 1120-1128. 2005.

https://doi.org/10.1016/j.compscitech.2004.11.007

[5] Maalej, M., Li, V. C. "Introduction of strain-hardening engineered cementitious composites in design of reinforced concrete flexural members for improved durability". ACI Structural Journal, 92(2), pp. 167-176. 1995. https://doi.org/10.14359/1150

[6] Kim, Y.Y., Fischer, G., Li, V. C. "Performance of bridge deck link slabs designed with ductile engineered cementitious composite". ACI structural Journal, 101(6), pp. 792-801. 2004.

https://doi.org/10.14359/13454

[7] Kojima, S., Sakata, N., Kamda, T. "Application of direct sprayed ECC for retrofitting dam structure surface-application for Mitaka-Dam". Concrete Journal, 42(5), pp. 135-139. 2004.

https://doi.org/10.3151/coj1975.42.5_135

[8] Kim, Y. Y., Fischer, G., Lim, Y. M., Li, V. "Mechanical performance of sprayed engineered cementitious composite using wet-mix shotcreting process for repair applications". ACI Materials Journal, 101(1), pp. 4249. 2004.

https://doi.org/10.14359/12986

[9] Maruta, M., Kanda, T., Nagai, S., Yamamoto, Y. "New high-rise RC structure using pre-cast ECC coupling beam". Concrete Journal, 43(11), pp. 18-26. 2005. https://doi.org/10.3151/coj1975.43.11_18

[10] Inaguma, H., Seki, M., Suda, K., Rokugo, K. "Experimental study on crack-bridging ability of ECC for repair under train loading". In: Proceedings of International Workshop on HPFRCC in Structural Applications. Rilem Publications, PRO. 2006.

[11] Zhang, Y., Lv, W., Peng, H. "Shear Resistance Evaluation of Strain-Hardening Cementitious Composites Membe". International Journal of Civil Engineering, 16(3), pp. 255-261. 2018.

https://doi.org/10.1007/s40999-016-0123-1

[12] Choi, H.-K., Bae, B.-I., Choi, C.-S. "Lateral resistance of unreinforced masonry walls strengthened with engineered cementitious composite". International Journal of Civil Engineering, 14(6), pp. 411-424. 2016. https://doi.org/10.1007/s40999-016-0026-1

[13] Li, V.C., Wang, S., Wu, C. "Tensile strain-hardening behavior of polyvinyl alcohol engineered cementitious composite (PVA-ECC)". Materials Journal, 98(6), pp. 483-492. 2001.

https://doi.org/10.14359/10851
[14] Swamy, R. N. "Fibre Reinforced Cement and Concrete: Proceedings of the Fourth International Symposium". Held by RILEM (the International Union of Testing and Research Laboratories for Materials and Structures) and Organized by the Department of Mechanical and Process Engineering, University of Sheffield, UK, Sheffield, July 20-23, 1992. Vol. 17. 1992. CRC Press, London. 1992.

[15] Aydin, S. "Effects of fiber strength on fracture characteristics of normal and high strength concrete". Periodica Polytechnica Civil Engineering, 57(2), pp. 191-200. 2013.

https://doi.org/10.3311/PPci.7174

[16] Erdélyi, A. "The toughness of steel fibre reinforced concretes". Periodica Polytechnica Civil Engineering, 37(4), pp. 329-344. 1993.

https://pp.bme.hu/ci/article/view/3826

[17] Vignesh, P., Krishnaraja, R., Nandhini, N. "Study on mechanical properties of geo polymer concrete using $\mathrm{m}$-sand and glass fibers". International Journal of Innovative Research in Science, Engineering and Technology, 3(S2), pp. 110-116. 2014. https://www.ijirset.com/upload/2014/special/ tapsa/19_TAPSACIVIL006.pdf

[18] Balaji, S., Thirugnanam, G. "Behaviour of reinforced concrete beams with SIFCON at various locations in the beam". KSCE Journal of Civil Engineering, 22(1) pp. 161-166. 2018.

https://doi.org/10.1007/s12205-017-0498-9

[19] Krishnaraja, A. R., Kandasamy, S. "Mechanical Properties of Engineered Cementitious Composites". International Journal of ChemTech Research, 10(8), pp. 341-347. 2017. http://www.sphinxsai.com/2017/ ch_vol10_no8/2/(341-347)V10N8CT.pdf

[20] Karatas, M., Gunes, A. "Engineering Properties of Self-Compacting Concrete Produced by Polypropylene and Steel Fiber". Periodica Polytechnica Civil Engineering, 59(2), pp. 95-102. 2015.

https://doi.org/10.3311/PPci.7348

[21] Krishnaraja, A., Kandasamy, S. "Flexural Performance of Engineered Cementitious Compositelayered Reinforced Concrete Beams". Archives of Civil Engineering. 63(4), pp. 173-189. 2018.

https://doi.org/10.1515/ace-2017-0048

[22] Czoboly, O., Lublóy, E., Hlavička, V., Balázs, Gy. L., Kéri, O., Szilágyi, I. "Fibers and fiber cocktails to improve fire resistance of concrete". Journal of Thermal Analysis and Calorimetry, 128(3), pp. 1453-1461. 2017. https://doi.org/10.1007/s10973-016-6038-x

[23] IS 10262 (2009): Guidelines for concrete mix design proportioning [CED 2: Cement and Concrete]. 2009. http://www.iitk.ac.in/ce/test/IS-codes/ is.9103.1999.pdf

[24] IS 9103 (1999): Concrete Admixtures [CED 2: Cement and Concrete] 1999. http://www.iitk.ac.in/ce/test/IS-codes/is.9103.1999.pdf

[25] Krishnamoorthy, M., Tensing, D., Sivaraja, M. "Durability Studies on Polyethylene Terephthalate (PET) Fibre Reinforced Concrete". International Journal of Civil Engineering and Technology, 8(10), pp. 634640. 2017. http://www.iaeme.com/MasterAdmin/UploadFolder/IJCIET_08_10_066/IJCIET_08_10_066.pdf

[26] Felekoğlu, B., Tosun, K., Baradan, B. "Effects of fibre type and matrix structure on the mechanical performance of self-compacting micro-concrete composites". Cement and Concrete Research, 39(11), pp. 10231032. 2009.

https://doi.org/10.1016/j.cemconres.2009.07.007

[27] Balázs, Gy. L., Czoboly, O., Lublóy, E., Kapitány, K., Barsi, A. "Observation of steel fibres in concrete with Computed Tomography". Construction and Building Materials, 140, pp. 534-541. 2017.

https://doi.org/10.1016/j.conbuildmat.2017.02.114

[28] IS 4031-6 (1988): Methods of physical tests for hydraulic cement, Part 6: Determination of compressive strength of hydraulic cement (other than masonry cement) [CED 2: Cement and Concrete]. Indian Standard, New Delhi, 1988. http://www.iitk.ac.in/ce/test/IS-codes/is.4031.6.1988.pdf 
[29] Bang, J. W., Prabhu, G. G., Jang, II. Y., Kim, Y. Y. "Development of Ecoefficient Engineered Cementitious Composites Using Supplementary Cementitious Materials as a Binder and Bottom Ash Aggregate as Fine Aggregate". International Journal of Polymer Science, 2015. Article ID 681051, 12 pages. 2015.

https://doi.org/10.1155/2015/681051

[30] Jang, S.-J., Kang, D.-H., Ahn, K.-L., Yun, H.-D. "Strain-Hardening and Cracking Behavior of Fiber-Reinforced Sustainable Cement Composites under Direct Tension". Computational Engineering Science, 8(17), pp. 757-764. 2015. http://www.m-hikari.com/ces/ces2015/ces17-20-2015/p/ jangCES17-20-2015.pdf

[31] Pan, Z., Wu, C., Liu, J., Wang, W., Liu, J. "Study on mechanical properties of cost-effective polyvinyl alcohol engineered cementitious composites (PVA-ECC)". Construction and Building Materials, 78, pp. 397-404. 2015. https://doi.org/10.1016/j.conbuildmat.2014.12.071

[32] Jang, S.-J., Rokugo, K., Park, W.-S., Yun, H.-D. "Influence of rapid freeze-thaw cycling on the mechanical properties of sustainable strainhardening cement composite (2SHCC)". Materials, 7(2), pp. 1422-1440. 2014.

https://doi.org/10.3390/ma7021422

[33] Sivaraja, M., Kandasamy, S. "Characterization of concrete composites for energy absorption". Journal of Reinforced Plastics and Composites, 27(2), pp. 135-144. 2008. https://doi.org/10.1177/0731684407081444

[34] Sivaraja, M., Kandasamy, S., Thirumurugan, A. "Mechanical strength of fibrous concrete with waste rural materials". Journal of Scientific and Industrial Research (JSIR), 69(4), pp. 308-312. 2010. http://nopr.niscair. res.in/handle/123456789/7718
[35] Balaji, S., Thirugnanam, G. "Flexural Strengthening of reinforced concrete beams using precast SIFCON laminates". Journal of structural Engineering, 40, pp. 262-267. 2013.

[36] Pakravan, H. R., Jamshidi, M., Latifi, M. "Study on fiber hybridization effect of engineered cementitious composites with low-and high-modulus polymeric fibers". Construction and Building Materials, 112, pp. 739746. 2016.

https://doi.org/10.1016/j.conbuildmat.2016.02.112

[37] Soe, K. T., Zhang, Y., Zhang, L. "Material properties of a new hybrid fibre-reinforced engineered cementitious composite". Construction and Building Materials, 43, pp. 399-407. 2013. https://doi.org/10.1016/j.conbuildmat.2013.02.021

[38] Li, V. "Engineered Cementitious Composites (ECC) Material. Structural, and Durability Performance". In: Concrete Construction Engineering Handbook. (Nawy, E. (Ed.)). Chapter 24. CRC Press, Boca Raton 2008. https://doi.org/10.1201/9781420007657.ch24

[39] Wang, T. "Control of cracking in engineering structure: principle of 'resist and release' for alternative bay construction method cracking control of super long mass concrete". China Architecture \& Building Press, Beijing, 2007.

[40] Feng, N., Gu, Q., Hao, T. "Cracking in concrete structure and its countermeasures". China Machine Press, Beijing. 2006.

[41] Xu, S. L., Wang, N., Zhang, X. "Flexural behavior of plain concrete beams strengthened with ultra high toughness cementitious composites layer". Materials and structures, 45(6), pp. 851-859. 2012. https://doi.org/10.1617/s11527-011-9803-0 